\title{
nature
}

\section{Chinese hesitancy on avian flu}

\author{
The time has come for China to start pulling its weight as a participant in the global response to bird flu - \\ and to learn to collaborate more openly.
}

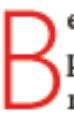
eijing is currently undertaking some spectacularly expensive preparations for hosting the $\mathbf{2 0 0 8}$ Olympics, and its government officials talk of sending a man to the Moon. But when it comes to the more prosaic matter of taking elementary precautions against the palpable economic and public-health risks posed by bird flu, the world's most ebullient industrial power is pleading poverty.

When representatives of about 100 countries met in the Chinese capital last week to discuss funding for countermeasures to the spread of avian influenza in nations far poorer than China itself, the host country was ready to offer only US $\$ 10$ million of the $\$ 1.9$ billion pledged in total over three years. China can point to the resource requirements of its own mitigation strategies as a reason for its reluctance to send money abroad. But this explanation would carry more weight if the country had put convincing strategies in place and openly shared information and biological samples with the outside world. So far, it has failed to do so.

Epidemiologists say that the most important initial steps in constraining both the spread of avian flu and its mutation into a strain that could cause a global human pandemic are the establishment of monitoring systems to track the virus in poultry and wild birds, and the rapid diagnosis and follow-up of all human cases. Needy countries at high risk of exposure to the virus, such as Indonesia and Cambodia, urgently require help in setting up such systems.

China has some 14 billion poultry, many of them scattered about in backyard farms in intimate contact with other livestock and people, so it is one of the most likely breeding-grounds for a pandemic virus. Collating accurate information about the virus populations circulating in these birds is a considerable challenge. Outsiders like to accuse Chinese government officials of cover-ups, but the reality is often that the officials themselves don't know what is happening on the ground.

Every nation struggles to align central-government strategy with local implementation, but in China the problem is particularly acute. It has taken years for the government to formulate a response to the HIV epidemic that has been emerging before its eyes. Severe acute respiratory syndrome (SARS) first appeared in China in November
2002, but it took months for Beijing to learn of the problem, acknowledge it and orchestrate a response. And with regard to bird flu, officials last summer claimed to be unaware that the widespread misuse of antiviral drugs by Chinese chicken farmers had already rendered them virtually ineffective (see Nature 435, 1009; 2005).

With something that will move as rapidly as bird flu, China needs a surveillance system that brings accurate information to the centre. Once it has that, the information should be shared with scientists abroad. Such sharing of information is another thing to which Beijing has historically been averse. Last spring, for example, foreign scientists were allowed only limited access to sites of early outbreaks of bird flu in western China.

The preferred crisis-response mode of senior Chinese officials, ingrained over decades, is first to identify a problem, then take measures to address it, and only afterwards report the improving situation to the outside world. The outbreak of SARS was sup-
"Sharing of information is something to which Beijing has historically been averse." posed to have demonstrated that this approach is no longer good enough. There are indeed signs that some lessons have been learned. Public-health provision has improved in the affected areas, and investigations into the disease have strengthened some aspects of Chinese biomedical research (see page 382 ).

In the case of SARS, mainland China eventually shared data on the virus responsible with scientists in Hong Kong and abroad, who were able to identify it and help to develop effective control measures. China should speed up this process for avian flu, making samples and genetic data for circulating strains immediately available. Access to outbreak areas should also be granted to international teams seeking epidemiological data. Data and samples from strains that have crossed over to humans also need to be shared. So far, this hasn't been happening. China's response to bird flu has been a mixture of secrecy and parsimony that does little to serve the interests of its farmers or its people, and is not becoming of an emerging world power.

\section{A firm foundation?}

\section{After more than thirty years, a European science agency is struggling to establish a clear identity.}

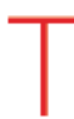
he European Science Foundation (ESF) was born before its time, in 1974 - and has suffered for it. It could have evolved into Europe's answer to the US National Science Foundation, but history decreed otherwise. Instead, it has pottered gently along, doing small things reasonably well. It has established high-quality research networks and conferences, and has published, on an ad-hoc basis, thoughtful documents on such policy issues as Europe's need for synchrotron facilities. But it has never really established a strong identity, and repeated exercises to carve out a lead role in the fragmented drama of European science have tended to fizzle out.

The latest such exercise, conducted last year at the request of its member organizations, may yet meet the same fate. It produced a somewhat watery-sounding mission statement that the ESF should serve as "a common platform for its member organisations in order 